\title{
$\mathrm{K}_{2} \mathrm{SiO}_{3} / \mathrm{C}$ 颗粒催化大豆油酯交换制备生物柴油
}

\author{
王建勋 ${ }^{1}$, 陈洸艟 ${ }^{2}$, 陈锦章 ${ }^{1, *}$ \\ '台中教育大学科学应用与推广学系, 台湾台中 40306 \\ 2 明新科技大学自然科学教学中心, 台湾新竹 30401
}

\begin{abstract}
摘要: 采用浸渍法将钾水玻璃负载于碳颗粒 (粒径 $1 \sim 3.5 \mathrm{~mm}$ ) 上, 经 $120^{\circ} \mathrm{C}$ 烘干后制得 $\mathrm{K}_{2} \mathrm{SiO}_{3} / \mathrm{C}$ 催化剂. 以 $\mathrm{X}$ 射线衍射、扫 瞄电镜-能量色散 X 射线与 Hammett 指示剂等方法对样品进行了表征. 以 $\mathrm{K}_{2} \mathrm{SiO}_{3} / \mathrm{C}$ 为催化剂, 大豆油为原料, 进行酯交换反应 制备生物柴油, 考察了催化剂用量、醇/油摩尔比、反应时间 (微波与传统加热) 等因素对大豆油酯交换率的影响. 当醇/油摩尔 比 30:1, 催化剂用量 $24 \mathrm{wt} \%$ 时, 传统加热反应于 $2.5 \mathrm{~h}$ 达到 $96.5 \%$ 酯交换率, 而相同条件下微波加热反应于 $1.5 \mathrm{~h}$ 达到 $96.7 \%$ 酯交换率。
\end{abstract}

关键词: 生物柴油; 固体催化剂; 钾水玻璃; 碳颗粒; 微波吸收

中图分类号: O643 文献标识码: A

收稿日期: 2011-05-27. 接受日期: 2011-07-26.

*通讯联系人. 电话: (886)-4-22183406; 传真: (886)-4-22183560; 电子信箱: ccchen@ms3.ntcu.edu.tw

基金来源：台湾”国家”科学委员会 (NSC99-2622-M-42-001-CC1).

本文的英文电子版(国际版)由Elsevier出版社在ScienceDirect上出版(http://www.sciencedirect.com/science/journal/18722067).

\section{Biodiesel Production from Soybean Oil Catalyzed by $\mathrm{K}_{2} \mathrm{SiO}_{3} / \mathrm{C}$}

\author{
WANG Jianxun ${ }^{1}$, CHEN Kungtung ${ }^{2}$, CHEN Chiingchang ${ }^{1, *}$ \\ ${ }^{1}$ Department of Science Application and Dissemination, National Taichung University of Education, Taichung 40306, Taiwan, China \\ ${ }^{2}$ The Teaching Center of Natural Science, Minghsin University of Science and Technology, Hsinchu 30401, Taiwan, China
}

\begin{abstract}
A solid base catalyst $\left(\mathrm{K}_{2} \mathrm{SiO}_{3} / \mathrm{C}\right)$ capable of microwave absorption was used for the transesterification of soybean oil under microwave radiation. The $\mathrm{K}_{2} \mathrm{SiO}_{3} / \mathrm{C}$ catalyst was prepared by an impregnation method that loaded $\mathrm{K}_{2} \mathrm{SiO}_{3}$ on carbon particles (1-3.5 mm diameter) followed by drying at $120^{\circ} \mathrm{C}$. The catalysts were characterized by X-ray diffraction, scanning electron microscopy- energy dispersive spectrometry, and the Hammett indicator method. $\mathrm{K}_{2} \mathrm{SiO}_{3}$ was well distributed on the support. The effects of reaction variables such as catalyst loading, molar ratio of methanol to oil, and reaction time (under microwave radiation and conventional heating) were studied. When the conventionally heated reaction was carried out at $65{ }^{\circ} \mathrm{C}$ with a methanol/oil molar ratio of $30: 1$ and a catalyst concentration of 24 wt $\%$, the biodiesel conversion was $96.5 \%$ after $2.5 \mathrm{~h}$ reaction time. The same reaction reached equilibrium after $1.5 \mathrm{~h}$ under microwave radiation, and the conversion of biodiesel was $96.7 \%$.
\end{abstract}

Key words: biodiesel; solid catalyst; potash water glass; carbon particle; microwave absorption

Received 27 May 2011. Accepted 26 July 2011.

*Corresponding author.Tel: +886-4-22183406; Fax: +886-4-22183560; E-mail: ccchen@ms3.ntcu.edu.tw

This work was supported by the "National" Science Council of Taiwan (NSC99-2622-M-42-001-CC1).

English edition available online at Elsevier ScienceDirect (http://www.sciencedirect.com/science/journal/18722067).

Global warming due to the heavy consumption of fossil resources and the depletion of natural resources is of increasing concern, and for sustainable development, biodiesel is of increasing attention as a source of renewable energy. The most common way to produce biodiesel is by transesterification. Although transesterification is relatively fast and has high conversions in homogeneous catalyst systems, these have some serious drawbacks [1] such as that the catalyst cannot be recovered and must be neutralized, and the separation of fatty acid methyl esters (FAME) from 
the catalyst during the process also generates large volumes of wastewater. These problems have led to the search for stable and more environmentally friendly solid catalysts. A literature survey indicated that alkali earth oxides, such as $\mathrm{CaO}, \mathrm{SrO}$, and $\mathrm{MgO}$, are the main solid catalysts used for the transesterification reaction [2-4]. Alkali metals or alkali earth salts loaded on metal oxide such as $\mathrm{KOH} / \mathrm{Al}_{2} \mathrm{O}_{3}$ [5], $\mathrm{KF} / \mathrm{MgO}$ [6], KI/MCM-41 [7], $\mathrm{Ca}\left(\mathrm{NO}_{3}\right)_{2} / \mathrm{Al}_{2} \mathrm{O}_{3}$ [8], and calcined $\mathrm{Mg}$-Al hydrotalcites $[9,10]$ have also been used in recent years.

In recent years, microwave (MW) technology has attracted the attention of researchers due to its unique molecular level heating to give rapid thermal reactions [11]. Many studies on the application of MW dielectric heating have been reported with homogeneous and heterogeneous catalysts in biodiesel production [12,13]. In this study, a solid catalyst $\left(\mathrm{K}_{2} \mathrm{SiO}_{3} / \mathrm{C}\right)$ was evaluated as a nonconventional basic solid that can absorb microwave irradiation resulting in energy absorption. It is well known that carbon materials can strongly absorb microwave energy. Due to its non-uniformity, "hot spots" can be generated on the surface of carbon materials where the temperatures (above $1200^{\circ} \mathrm{C}$ ) are higher than at other places, and where chemical reactions can easily take place [14].

Alkali-silicate binders have been known for a long time and the mechanism of solidification in the sol-gel technique of materials preparation has been gradually understood [15]. A $\mathrm{K}_{2} \mathrm{SiO}_{3}$ solution used to supply basic sites supported on carbon particles for the transesterification reaction has not been reported. The catalytic performance of the $\mathrm{K}_{2} \mathrm{SiO}_{3} / \mathrm{C}$ catalyst was studied to provide a solid base catalyst for the production of biodiesel.

\section{Experimental}

\subsection{Preparation of the catalyst}

The $\mathrm{K}_{2} \mathrm{SiO}_{3} / \mathrm{C}$ catalysts were prepared by an impregnation method. Typically, a required amount of $\mathrm{K}_{2} \mathrm{SiO}_{3}$ solution (reagent grade, 66.2\%, Shimakyu's Pure Chemicals) was diluted with $200 \mathrm{ml}$ deionized (DI) water at ambient temperature. The carbon particles (Taiwan Active Carbon Industry Co., dried at $80{ }^{\circ} \mathrm{C}$ for $3 \mathrm{~h}$ before being used), which was an irregular type of particle size 1-3.5 mm, was then added into the solution followed by vigorous mixing. The amount of $\mathrm{K}_{2} \mathrm{SiO}_{3}$ solution/carbon was varied from 10 $\mathrm{wt} \%$ to $30 \mathrm{wt} \%$. After equilibrating the mixture for $1 \mathrm{~h}$, the resulting solution was dried in an oven at $120^{\circ} \mathrm{C}$ for $24 \mathrm{~h}$.

\subsection{Transesterification reaction procedure}

The transesterification reaction was performed in a 250 $\mathrm{ml}$ flat-bottom flask equipped with a reflux condenser and a magnetic stirrer. The transesterification reaction of soybean oil (Great Wall Enterprise Co.) and methanol (ACS grade, ECHO Chemical Co.) was carried out in the liquid phase under atmospheric pressure at $65{ }^{\circ} \mathrm{C}$ while stirring at 600 $\mathrm{r} / \mathrm{min}$ for $0.5-3 \mathrm{~h}$. The microwave reactions were carried out in a microwave synthesis reactor (CEM, MARS) working at $2.45 \mathrm{GHz}$ and rated at $150 \mathrm{~W}$. The temperature of the reaction mixture was maintained by a fiber optic temperature sensor (Model: Discover Fiberoptic, CEM; range: -50 to $250{ }^{\circ} \mathrm{C}$ ). For the conventional heating method, a hot plate was used for heating the mixture in the flask. The heating power of the hot plate was $700 \mathrm{~W}$.

After the transesterification reaction, DI water was added into the reaction mixture to stop the reaction. The supernatant was filtrated through a filter paper, and excess methanol and water were evaporated before the analysis of the FAMEs.

\subsection{Characterization of the catalyst}

The basic strength of the samples $\left(H_{-}\right)$was determined by Hammett indicators [6]. The Hammett indicators for basic site strength used were: bromthymol blue $\left(H_{-}=7.2\right)$, phenolphthalein $\left(H_{-}=9.8\right), 2,4$-dinitroaniline $\left(H_{-}=15.0\right)$, and 4-nitroaniline $\left(H_{-}=18.4\right)$. About $1 \mathrm{~g}$ of sample was shaken with $10 \mathrm{ml}$ methanol solution of the Hammett indicator and left for $1 \mathrm{~h}$ to achieve equilibration. The total number of basic sites was determined by titration with benzoic acid in methanol using phenolphthalein as the indicator [6]. The X-ray diffraction (XRD) characterization of the catalysts was performed on a MAC MXP18 powder X-ray diffractometer using $\mathrm{Cu} K_{\alpha}$ radiation over a $2 \theta$ range from $20^{\circ}$ to $80^{\circ}$ with a step size of $0.04^{\circ}$ at a scanning speed of $3 \%$ min. The microstructures of the $\mathrm{K}_{2} \mathrm{SiO}_{3} / \mathrm{C}$ catalysts were observed by a field emission scanning electron microscope (SEM, JEOL JSM-7401F). The FAME concentration, used to express the biodiesel purity of the product, was determined by a gas chromatograph (Thermo trace GC ultra) equipped with a flame ionization detector and a capillary column (Tr-biodiesel $(\mathrm{F})$, Thermo, $30 \mathrm{~m} \times 0.25 \mathrm{~mm} \times 0.25$ $\mu \mathrm{m})$. Nitrogen was used as the carrier gas. The amount of FAME was calculated by the internal standard (methyl heptadecanoate) method according to Chinese National Standards 15051 . In order to quantitatively evaluate leaching of the solid base catalyst under the reaction conditions, some parts of the samples taken from the reactor were carefully filtered, and the residual methanol was evaporated in a rotary evaporator so that the FAME and glycerol were left as a separate phase. After the evaporation, the dry fraction was treated with $0.1 \mathrm{~mol} / \mathrm{L}$ hydrochloric acid [16]. The resulting solution was analyzed by inductively coupled plasma opti- 
cal emission spectroscopy (ICP-OES, Spectro Genesis) to determine the $\mathrm{K}$ concentration.

\section{Results and discussion}

The catalytic activities of carbon particles with different $\mathrm{K}_{2} \mathrm{SiO}_{3}$ loadings were measured. For comparison, the same reaction conditions shown in Table 1 were employed in all experiments. The reaction conditions were not optimized for the highest reaction conversion. Non- loaded carbon particles exhibited no activity. When $\mathrm{K}_{2} \mathrm{SiO}_{3}$ was loaded on the carbon particles, the supported catalysts showed catalytic activity. It can be concluded that the observed activities of the carbon supported catalysts were due to their basicity, i.e., a higher basicity result in a higher conversion.

Figure 1 shows the XRD patterns of ground original carbon particles and catalyst particles (loading of $30 \mathrm{wt} \%$ $\mathrm{K}_{2} \mathrm{SiO}_{3}$ solution). The carbon particles and prepared catalyst particles had the same XRD patterns which was identical to that of $\mathrm{C}$ (PDF 261077). No characteristic peak due to $\mathrm{K}_{2} \mathrm{SiO}_{3}$ or any new species such as $\mathrm{KOH}$ and $\mathrm{SiO}_{2}$ was observed, indicating the high dispersion of $\mathrm{K}_{2} \mathrm{SiO}_{3}$ on the carbon support [17].

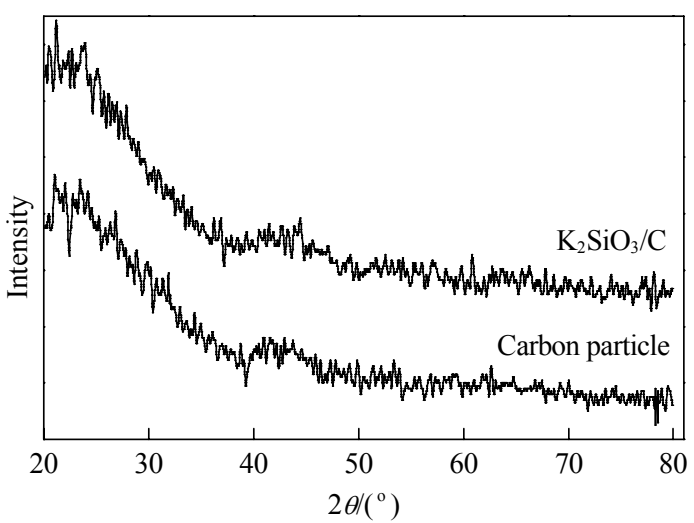

Fig. 1. XRD patterns obtained from ground original carbon particle and catalyst particle.

Figure 2 shows typical SEM and EDS mapping images of the $\mathrm{K}_{2} \mathrm{SiO}_{3} / \mathrm{C}$ catalyst ( $30 \% \mathrm{~K}_{2} \mathrm{SiO}_{3}$ solution loading) and a used $\mathrm{K}_{2} \mathrm{SiO}_{3} / \mathrm{C}$ catalyst. These showed that the morphology was irregular and diverse, with smooth surfaces, large pores, and convex surfaces. The distribution of $\mathrm{K}_{2} \mathrm{SiO}_{3}$ on the support surface was homogeneous even on the convex surfaces and in the large pores. $\mathrm{K}_{2} \mathrm{SiO}_{3}$ was found to be very effectively distributed on the surface of the support. In order

Table 1 Properties of $\mathrm{K}_{2} \mathrm{SiO}_{3} / \mathrm{C}$ particles used as solid base catalyst for the transesterification of soybean oil with refluxing methanol

\begin{tabular}{lcccc}
\hline Catalyst & $\mathrm{K}_{2} \mathrm{SiO}_{3}$ solution loading $(\mathrm{wt} \%)$ & Basic strength & Basicity $H_{-}>9.8(\mathrm{mmol} / \mathrm{g})$ & Conversion \\
\hline Carbon & 0 & $H_{-}<7.2$ & 0 & 0 \\
$\mathrm{~K}_{2} \mathrm{SiO}_{3} / \mathrm{C}$ & 10 & $7.2<H_{-}<9.8$ & 0.018 \\
$\mathrm{~K}_{2} \mathrm{SiO}_{3} / \mathrm{C}$ & 15 & $9.8<H_{-}<15.0$ & 0.043 \\
$\mathrm{~K}_{2} \mathrm{SiO}_{3} / \mathrm{C}$ & 20 & $9.8<H_{-}<15.0$ & 0.053 \\
$\mathrm{~K}_{2} \mathrm{SiO}_{3} / \mathrm{C}$ & 25 & $9.8<H_{-}<15.0$ & 0.052 \\
$\mathrm{~K}_{2} \mathrm{SiO}_{3} / \mathrm{C}$ & 30 & $9.8<H_{-}<15.0$ & 83.3 & 82.0 \\
\hline
\end{tabular}

*Reaction conditions: $12.5 \mathrm{~g}$ soybean oil, methanol/oil molar ratio 24:1, catalyst amount $2 \mathrm{~g}$, reaction time $3 \mathrm{~h}$, at the methanol reflux temperature with conventional heating.
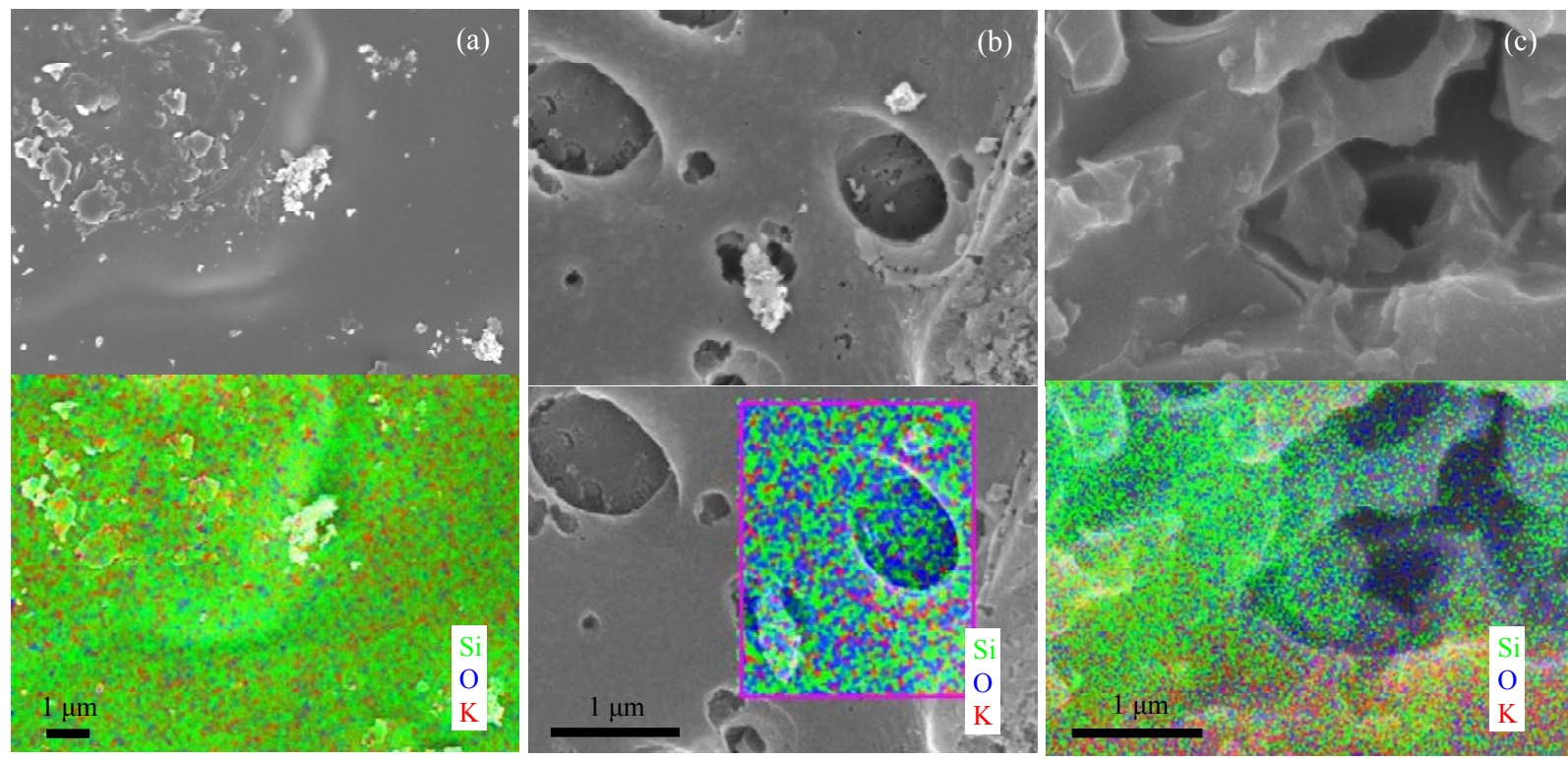

Fig. 2. SEM and EDS mapping of samples. (a) and (b) Fresh $\mathrm{K}_{2} \mathrm{SiO}_{3} / \mathrm{C}$ catalyst; (c) Used $\mathrm{K}_{2} \mathrm{SiO}_{3} / \mathrm{C}$ catalyst. 
to remove adsorbed species from the catalyst surface, the used $\mathrm{K}_{2} \mathrm{SiO}_{3} / \mathrm{C}$ catalysts were washed with anhydrous methanol and dried at $120{ }^{\circ} \mathrm{C}$ for $24 \mathrm{~h}$ before examination by $\mathrm{SEM} . \mathrm{K}_{2} \mathrm{SiO}_{3}$ was found to be well distributed on the surface of the support even after the transesterification reaction.

In order to compare the microwave absorption ability of carbon particles $\left(30 \% \mathrm{~K}_{2} \mathrm{SiO}_{3}\right.$ solution loading), $\mathrm{CaO}$ powder and $\mathrm{K}_{2} \mathrm{SiO}_{3}$ powder $\left(\mathrm{K}_{2} \mathrm{SiO}_{3}\right.$ solution dried at $120{ }^{\circ} \mathrm{C}$ for $24 \mathrm{~h}$ and then well ground), a $25 \mathrm{~g}$ sample was placed in a glass reactor with an i.d. of $57 \mathrm{~mm}$ that was heated at 2.45 $\mathrm{GHz}$ with $150 \mathrm{~W}$. The catalyst temperature was measured by a fiber optic temperature sensor located in the sample. In Fig. 3, it is clearly shown that $\mathrm{K}_{2} \mathrm{SiO}_{3} / \mathrm{C}$ is much more effective in absorbing microwave than $\mathrm{K}_{2} \mathrm{SiO}_{3}$ and $\mathrm{CaO}$ since it had a much higher temperature. Therefore, the $\mathrm{K}_{2} \mathrm{SiO}_{3} / \mathrm{C}$ catalyst showed a higher energy efficiency and would have a faster reaction rate to shorten the reaction time under microwave irradiation.

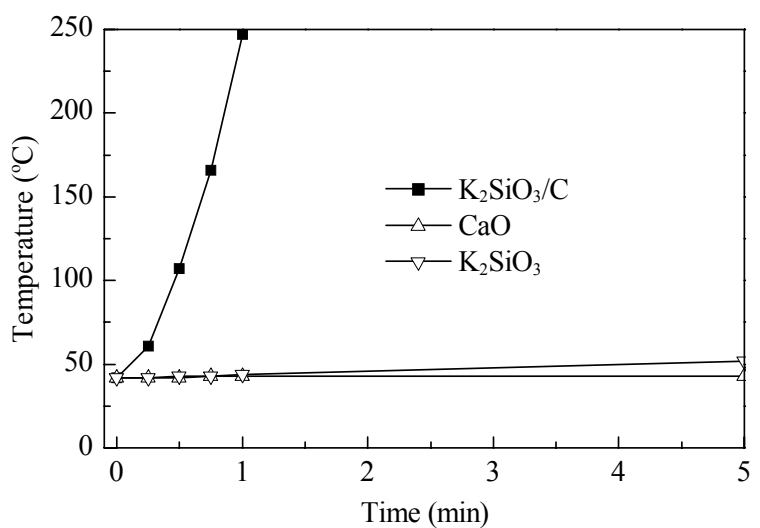

Fig. 3. Temperature profiles of $\mathrm{K}_{2} \mathrm{SiO}_{3} / \mathrm{C}, \mathrm{CaO}$, and $\mathrm{K}_{2} \mathrm{SiO}_{3}$ under $150 \mathrm{~W}$ microwave heating of $25 \mathrm{~g}$ sample.

The variables investigated included the catalyst amount, alcohol/oil ratio, and reaction time for the $\mathrm{K}_{2} \mathrm{SiO}_{3} / \mathrm{C}$ catalyst ( $30 \% \mathrm{~K}_{2} \mathrm{SiO}_{3}$ loading). The catalyst amount was varied in the range of 1-6 g. As shown in Fig. 4, the conversion increased as the catalyst amount was increased to $1-3 \mathrm{~g}$. The conversion reached a plateau value for the catalyst mass of 4-6 g.

In heterogeneous catalysis, mass transfer and reactant adsorption on the catalyst are very important; thus, a molar ratio higher than the stoichiometric molar ratio of methanol is needed to shift the equilibrium of the reaction. As shown in Fig. 5, when the methanol loading increased, the conversion increased considerably. The maximum conversion was $96.6 \%$ at the methanol/oil molar ratio of $36: 1$.

To study the effect of microwave radiation and conventional heating on the conversion, experiments were carried out using a $\mathrm{K}_{2} \mathrm{SiO}_{3} / \mathrm{C}$ catalyst. As shown in Fig. 6, the reaction reached equilibrium after $1.5 \mathrm{~h}$ under microwave radia-

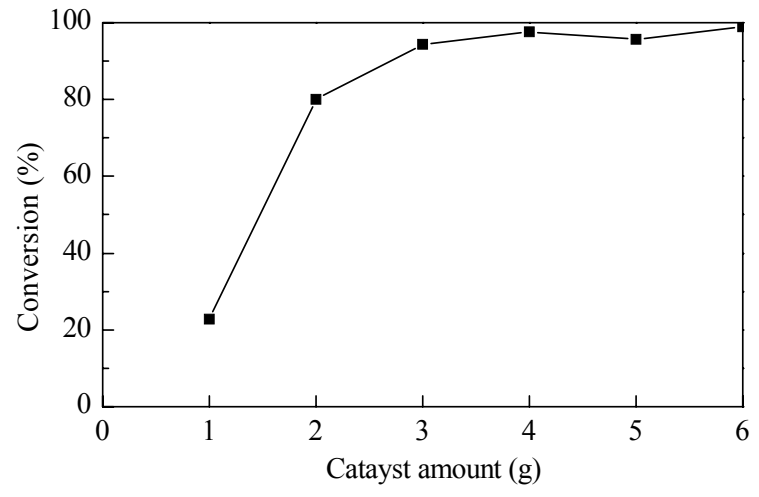

Fig. 4. Influence of catalyst amount on the conversion using conventional heating. Reaction conditions: $12.5 \mathrm{~g}$ soybean oil, methanol/oil molar ratio $24: 1$, reaction time $3 \mathrm{~h}$, reaction temperature $65^{\circ} \mathrm{C}$.

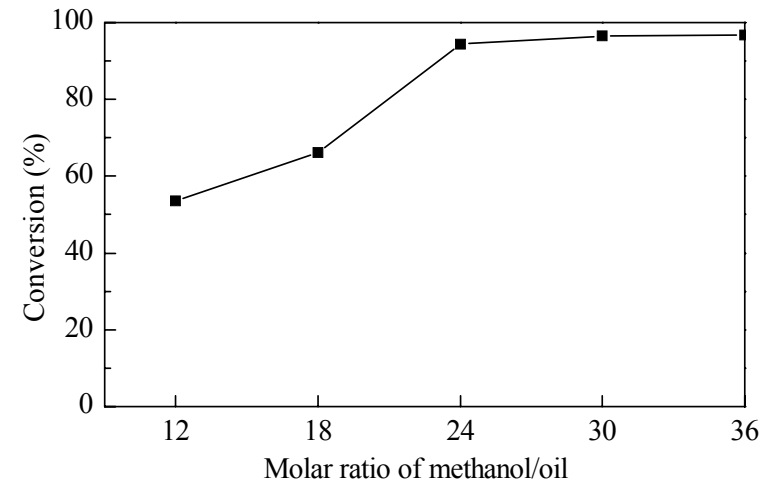

Fig. 5. Influence of methanol/oil molar ratio on the conversion using conventional heating. Reaction conditions: $12.5 \mathrm{~g}$ soybean oil, catalyst amount $3 \mathrm{~g}$, reaction time $3 \mathrm{~h}$, reaction temperature $65^{\circ} \mathrm{C}$.

tion. The conversion of biodiesel was $96.7 \%$. However, the reaction did not reach equilibrium when conventional heating was used for $2.5 \mathrm{~h}$. The conversion of biodiesel was $96.5 \%$. That is, a shorter time was needed under microwave radiation compared to conventional heating.

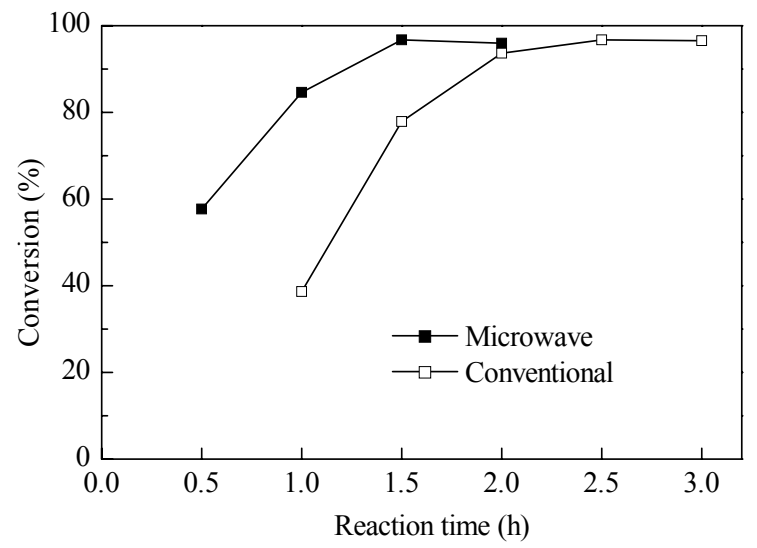

Fig. 6. Comparison of microwave radiation and conventional heating on the conversion. Reaction conditions: $12.5 \mathrm{~g}$ soybean oil, methanol/oil molar ratio 30:1, catalyst amount $3 \mathrm{~g}$. 
In order to study the stability of the $\mathrm{K}_{2} \mathrm{SiO}_{3} / \mathrm{C}$ catalyst, the samples were recovered by simple decantation. The remaining catalyst in the reactor was used to catalyze the next batch of soybean oil. A decline was observed in the conversion to methyl esters from $96.6 \%$ to $57.9 \%$, indicating the decrease of catalytic activity. This lowered activity may be explained by the dissolution of $\mathrm{K}$ species in the heterogeneous $\mathrm{K}_{2} \mathrm{SiO}_{3} / \mathrm{C}$ catalyst. Glycerol covering of the surface of catalyst was also considered as the reason for the activity loss. The stability of the $\mathrm{K}_{2} \mathrm{SiO}_{3} / \mathrm{C}$ catalyst was better than that of a $\mathrm{KOH} / \mathrm{NaX}[18]$ catalyst and $\mathrm{KOH} / \mathrm{MgO}$ catalyst [19]. After a recycling experiment, it was found that the catalytic activity of the $\mathrm{KOH} / \mathrm{NaX}$ catalyst and $\mathrm{KOH} / \mathrm{MgO}$ catalyst decreased to $48.7 \%$ biodiesel conversion and $26.45 \%$ biodiesel yield, respectively.

The solubility of the catalyst was also a very important factor that should be taken into account to correctly interpret the performance and assess its practical use. This was a very important issue since neutralization and washing steps of the biodiesel produced would be necessary if any metal was found in it. Then, the possible advantage of using the heterogeneous catalyst for this process would be nullified. The results showed that only small quantities (free $\mathrm{K}^{+}$concentration was $3.1 \mathrm{ppm}$ ) existed in the biodiesel. The results obtained proved that the $\mathrm{K}_{2} \mathrm{SiO}_{3} / \mathrm{C}$ catalyst prepared has good potential for the biodiesel production from soybean oil.

\section{Conclusions}

The $\mathrm{K}_{2} \mathrm{SiO}_{3} / \mathrm{C}$ catalyst was prepared by an impregnation method. $\mathrm{K}_{2} \mathrm{SiO}_{3}$ was well distributed on the surface of the carbon particle and it was an effective base for the transesterification reaction. Furthermore, the $\mathrm{K}_{2} \mathrm{SiO}_{3} / \mathrm{C}$ catalyst has good microwave absorption ability and showed high energy efficiency to give a faster reaction rate to shorten the reaction time.

\section{References}

1 Kumar D, Kumar G, Poonam, Singh C P. Ultrason Sonochem, 2010, 17: 555

2 朱华平, 吴宗斌, 陈元雄, 张萍, 段世杰, 刘晓华, 毛宗强. 催化学报 (Zhu H P, Wu Z B, Chen Y X, Zhang P, Duan Sh J, Liu X H, Mao Z Q. Chin J Catal), 2006, 27: 391

3 Liu X, He H, Wang Y, Zhu S. Catal Commun, 2007, 8: 1107

4 Demirbas A. Energy Sources, Part A, 2008, 30: 1645

5 Noiroj K, Intarapong P, Luengnaruemitchai A, Jai-In S. Renew Energy, 2009, 34: 1145

6 Wan T, Yu P, Gong S, Li Q, Luo Y. Korean J Chem Eng, 2008, 25: 998

7 Balbaşi M, Bartan A, Ar İ, Gürü M. Energy Sources, Part A, 2011, 33: 1035

8 Benjapornkulaphong S, Ngamcharussrivichai C, Bunyakiat K. Chem Eng J, 2009, 145: 468

9 Brito A, Borges M E, Garín M, Hernández A. Energy Fuels, 2009, 23: 2952

10 Chuayplod P, Trakarnpruk W. Ind Eng Chem Res, 2009, 48: 4177

11 Sun Y, Zhang Y, Quan X. Sep Purif Technol, 2008, 62: 565

12 Azcan N, Danisman A. Fuel, 2007, 86: 2639

13 Patil P D, Gude V G, Camacho L M, Deng S. Energy Fuels, 2010, 24: 1298

14 Ai Z, Wang Y, Xiao M, Zhang L, Qiu J. J Phys Chem C, 2008, 112: 9847

15 Ikeda K. Cem Concr Res, 1997, 27: 657

16 Arzamendi G, Arguiñarena E, Campo I, Zabala S, Gandía L M. Catal Today, 2008, 133-135: 305

17 Xie W, Li H. J Mol Catal A, 2006, 255: 1

18 Xie W, Huang X, Li H. Bioresour Technol, 2007, 98: 936

19 Ilgen O, Akin A N. Energy Fuels, 2009, 23: 1786 